\title{
Pengaruh temperatur biogas dan waktu penyalaan terhadap kinerja motor bakar menggunakan sistem dual fuel pertamax-biogas
}

\author{
Mafruddin $^{1^{\star}}$, Dwi Irawan ${ }^{2}$, Renno Y. P. ${ }^{3}$, Edwin D. P. ${ }^{4}$ \\ 1,2 Jurusan Teknik Mesin,Fakultas Teknik, Universitas Muhammadiyah Metro \\ ${ }^{3,4}$ Prodi Teknik Mesin,Fakultas Teknik, Universitas Muhammadiyah Metro \\ Jl. Ki Hajar Dewantara 15 A Kota Metro, Lampung, Indonesia \\ *Corresponding author: mafruddinmn@gmail.com
}

\begin{abstract}
Biogas is an alternative fuel that can be used to replace fossil fuels which are nonrenewable energy sources and their availability is decreasing. The use of biogas as fuel for gasoline engines can be done using a dual fuel system (Pertamax-Biogas). The combustion process in a gasoline engine with a dual fuel system is influenced by the temperature of the biogas and the ignition timing of the ignition system. The combustion process on a gasoline engine will affect the resulting performance. The purpose of this study was to determine the effect of biogas temperature and ignition timing on the performance of a motorcycle engine with a dual fuel system (Pertamax-Biogas). The method used in this study is an experimental study by testing the performance of a motorcycle engine using a dual fuel system (PertamaxBiogas) using fuel temperature variations of $30^{\circ}, 40^{\circ}$, and $50^{\circ} \mathrm{C}$ and ignition timing variations at $11^{\circ}, 13^{\circ}$ and $15^{\circ}$ before Top Dead Center (TDC). The results of the study it can be concluded that the biogas temperature and ignition timing affect the performance of the motor. The highest power is obtained by varying the biogas temperature to $40^{\circ} \mathrm{C}$ and the ignition time to $15^{\circ}$ before TDC, meanwhile the best specific fuel consumption was obtained at a biogas temperature variation of $50^{\circ} \mathrm{C}$ and an ignition time of $15^{\circ}$ before TDC.
\end{abstract}

Keywords: Dual fuel, biogas temperature, ignition time, motor performance.

\begin{abstract}
Abstrak
Biogas merupakan bahan bakar alternatif yang dapat digunakan untuk menggantikan bahan bakar fossil yang merupakan sumber energi tak terbarukan dan ketersediaan semakin berkurang. Penggunaan biogas sebagai bahan bakar motor bensin dapat dilakukan dengan menggunakan sistem dual fuel (Pertamax-Biogas). Proses pembakaran pada motor bakar bensin dengan sistem dual fuel dipengaruhi oleh temperatur biogas dan waktu penyalaan pada sistem pengapian. Proses pembakaran pada motor bakar bensin akan berpengaruh terhadap kinerja yang dihasilkan. Tujuan penelitian ini adalah untuk mengetahui pengaruh temperatur biogas dan waktu penyalaan terhadap kinerja mesin sepeda motor dengan sistem dual fuel (Pertamax-Biogas). Metode yang digunakan pada penelitian ini adalah penelitian eksperimental dengan pengujian kinerja mesin sepeda motor menggunakan sistem dual fuel (Pertamax-Biogas) menggunakan variasi temperatur bahan bakar $30^{\circ}, 40^{\circ}$, dan $50{ }^{\circ} \mathrm{C}$ dan variasi waktu penyalaan $11^{\circ}, 13^{\circ}$, dan $15^{\circ}$ sebelum Titik Mati Atas (TMA). Dari hasil penelitian dapat disimpulkan bahwa temperatur biogas dan waktu penyalaan berpengaruh terhadap kinerja motor. Daya tertinggi diperoleh dengan variasi temperatur biogas $40^{\circ} \mathrm{C}$ dan waktu penyalaan $15^{\circ}$ sebelum TMA, sedangkan konsumsi bahan bakar spesifik terbaik diperoleh pada variasi temperatur biogas $50^{\circ} \mathrm{C}$ dan waktu penyalaan $15^{\circ}$ sebelum TMA.
\end{abstract}

Kata kunci: Dual fuel, temperatur biogas, waktu penyalaan, kinerja motor.

\section{Pendahuluan}

Pertumbuhan penduduk dan perkembangan ekonomi di Indonesia semakin meningkat, hal tersebut akan sejalan dengan penggunaan energi. Namun pada saat ini sebagian besar sumber energi 
yang digunakan masih berasal dari bahan bakar fossil. Bahan bakar fossil merupakan sumber energi yang tak terbarukan, jika bahan bakar tersebut digunakan secara terus menerus maka cadangan bahan bakar fossil akan semakin berkurang bahkan habis. Maka dari itu perlu dilakukan penelitian tentang sumber bahan bakar alternatif untuk menggantikan sumber energi tak terbarukan.

Salah satu penggunaan bahan bakar fossil adalah pada kendaraan bermotor seperti sepeda motor, mobil dan alat transpotasi lainnya. Jenis bahan bakar yang digunakan pada sepeda motor akan berpengaruh terhadap kinerja mesin. Kinerja mesin sepeda motor dapat diukur dari torsi, daya, dan konsumsi bahan bakar spesifik yang mampu dihasilkan. Salah satu jenis bahan bakar yang bersumber dari energi terbarukan yang dapat digunakan pada mesin sepeda motor yaitu biogas. Hasil pengujian motor bensin satu silinder dapat hidup dengan baik setelah menggunakan biogas yang sudah melalui proses purifikasi [1].

Selain dapat menggunakan bahan bakar bensin, pertalite, dan pertamax, mesin sepeda motor bensin juga dapat menggunakan bahan bakar gas. Namun unjuk kerja dari mesin sepeda motor bensin cenderung menurun ketika menggunakan bahan bakar gas. Salah satu cara untuk meningkatkan unjuk kerja dari motor bensin yang menggunakan bahan bakar gas atau dual fuel (Bensin-Bahan Bakar Gas/BBG) adalah dengan mengatur pemajuan penyalaan secara elektronik sehingga waktu pengapiannya menjadi lebih tepat [2].

Selain jenis bahan bakar, faktor lain yang berpengaruh terhadap kinerja mesin sepeda motor yaitu waktu pengapian (Ignition Timing). Waktu pengapian merupakan kondisi terjadinya percikan bunga api pada busi dengan sudut poros engkol tertentu. Waktu pengapian dan compression ratio yang tepat dapat memberikan perbaikan unjuk kerja motor bensin secara signifikan dibandingkan hanya dengan variasi compression ratio [3].

Kinerja mesin sepeda motor juga dapat dipengaruhi oleh sistem masuk bahan bakar dan temperatur bahan bakar. Dengan temperatur yang tepat dapat meningkatkan kinerja mesin sepeda motor khususnya untuk konsumsi bahan bakar spesifik [4].

Pada penelitian ini dilakukan pengujian kinerja mesin sepeda motor dengan menggunakan sistem dual fuel (Biogas-Pertamax) dengan variasi temperatur biogas dan waktu pengapian. Dengan penelitian ini diharapkan mampu meningkatkan kinerja mesin sepeda motor dan dapat mengurangi penggunaan bahan bakar fosil.

Tujuan dari penelitian ini yaitu untuk mengetahui pengaruh temperatur biogas dan waktu pengapian terhadap torsi dan daya yang dihasilkan mesin sepeda motor serta konsumsi bahan bakar spesifik.

\section{Tinjauan Pustaka}

Pembakaran merupakan suatu reaksi kimia yang cepat antara unsur oksigen dan bahan bakar. Pada proses pembakaran akan menghasilkan cahaya dan juga menghasilkan energi dalam bentuk panas. Begitu juga pembakaran pada motor bensin. Tujuan utama pembakaran pada motor bensin yaitu menghasilkan panas (termal) yang selanjutnya panas tersebut digunakan untuk menggerakkan piston atau untuk melakukan gerakan mekanik. Pada motor bensin terdapat dua macam tipe, yaitu motor bakar 4 tak dan motor bakar 2 tak. Pada motor 4 tak, untuk melakukan satu siklus memerlukan 4 gerakan torak atau dua kali putaran poros engkol, sedangkan pada motor 2 tak, untuk melakukan satu siklus hanya memerlukan 2 gerakan torak atau satu putaran poros engkol. Motor bensin 4 langkah adalah motor bensin yang bekerja dengan 4 siklus yang berurutan yaitu, hisap, kompresi, kerja dan buang. Titik tertinggi yang dicapai oleh torak tersebut disebut titik mati atas (TMA) dan titik terendah disebut titik mati bawah (TMB). Gerakan dari TMA ke TMB 
disebut langkah torak (stroke). Pada motor 4 langkah mempunyai 4 langkah dalam satu gerakan yaitu langkah pengisapan, langkah kompresi, langkah kerja, dan langkah pembuangan [5].

Apabila suatu bahan bakar dipanaskan dengan temperatur tertentu maka akan terjadi pemuaian (perubahan volume) pada bahan bakar tersebut, selain itu viskositas (kekentalan) dari bahan bakar tersebut akan menurun. Peristiwa ini dapat dapat dijelaskan dengan teori Termodinamika yang menyatakan bahwa semakin tinggi temperatur suatu fluida, molekul fluida akan bergerak cepat, sehingga pada volume tetap secara makro akan meningkatkan tekanan. Jika tidak terdapat batas pada materi tersebut maka materi akan mengembang dan memperlebar jarak antar molekulnya. Jarak antar molekul yang lebar akan mengakibatkan kerapatan (densitas) dan viskositas semakin menurun begitu juga sebaliknya jika bahan bakar didinginkan maka volume akan menurun dan viskositasnyapun akan meningkat. Bahan bakar dengan viskositas rendah akan teratomisasi dengan lebih baik sehingga menghasilkan butiran bahan bakar yang lebih kecil. Dengan kondisi seperti ini maka proses pencampuran bahan bakar dengan udara akan lebih homogen sehingga bahan bakar yang terbakar lebih banyak. Karena bahan bakar yang terbakar lebih banyak, energi yang dilepaskan meningkat sehingga tekanan akhir pembakaran meningkat, artinya dengan jumlah volume bahan bakar yang sama yang masuk ke dalam ruang bakar, dapat menghasilkan daya yang berbeda [5].

Volume silinder pada motor bakar merupakan besarnya volume langkah torak atau piston (piston displacement) ditambah dengan besarnya volume ruang bakar. Volume langkah dapat dihitung dari volume di atas piston di TMB sampai garis TMA. Sedangkan volume ruang bakar pada motor bakar dapat dihitung berdasarkan volume di atas piston saat posisi piston berada di TMA. Volume ruang bakar biasa disebut dengan volume sisa. Torsi adalah ukuran kemampuan mesin untuk melakukan kerja, jadi torsi adalah suatu energi. Besaran torsi adalah besaran turunan yang biasa digunakan untuk menghitung energi yang dihasilkan dari benda yang berputar pada porosnya. Apabila suatu benda berputar dan mempunyai besar gaya sentrifugal sebesar $\mathrm{F}$, benda berputar pada porosnya dengan jari-jari sebesar b, maka torsinya adalah [6]:

$$
T=F x b
$$

Keterangan:

$$
T=\text { Torsi benda berputar }(\mathrm{Nm})
$$

$F \quad=$ Gaya dari benda berputar $(\mathrm{N})$

$b \quad=$ jarak benda ke pusat rotasi $(\mathrm{m})$

Daya poros adalah daya efektif pada poros yang akan digunakan untuk mengatasi beban kendaraan. Daya poros diperoleh dari pengukuran torsi pada poros yang dikalikan kecepatan sudut putarnya atau dapat dituliskan dengan persamaan sebagai berikut [6]:

$$
N_{e}=\omega . \mathrm{T}
$$

Keterangan:

$$
\begin{aligned}
N_{e} & =\text { Daya poros }(\mathrm{W}) \\
\mathrm{T} & =\text { Torsi }(\mathrm{Nm}) \\
\omega & =\operatorname{Kecepaatan} \text { sudut putar }(\mathrm{rad} / \mathrm{s}) \\
n & =\text { Putaran poros }(\mathrm{rpm})
\end{aligned}
$$

Tekanan efektif rata-rata adalah besarnya rata-rata tekanan yang dihasilkan dari pembakaran campuran bahan bakar dan udara. Untuk mengetahui tekanan efektif rata-rata dapat diketahui dengan persamaan berikut [6]:

$$
N_{e}=\frac{\mathrm{Pe} \cdot \mathrm{V}_{\mathrm{L}} \cdot \mathrm{n} \cdot \mathrm{a} \cdot \mathrm{z}}{60}
$$

Keterangan:

$$
\begin{aligned}
& N_{e}=\text { Daya Efektif }(\mathrm{W}) \\
& \mathrm{P}_{\mathrm{e}}=\text { Tekanan efektif rata-rata }\left(\mathrm{kg} / \mathrm{m}^{2}\right) \\
& \mathrm{V}_{\mathrm{L}}=\text { Volume langkah piston }\left(\mathrm{m}^{3}\right) \\
& \mathrm{n}=\text { Putaran mesin (rpm) } \\
& \mathrm{a} \quad=\text { Jumlah siklus perputaran } \\
& \mathrm{Z} \quad=\text { Jumlah silinder }
\end{aligned}
$$

Konsumsi bahan bakar merupakan jumlah bahan bakar yang dikonsumsi atau digunakan motor untuk menghasilkan tenaga mekanis atau energi mekanis, untuk mengetahui laju pemakaian bahan bakar tiap detiknya [7]. 
Laju pemakaian bahan bakar (konsumsi bahan bakar) spesifik atau spesific fuel consumtion (SFC) adalah jumlah bahan bakar $(\mathrm{kg})$ per waktunya untuk menghasikan daya sebesar $1 \mathrm{HP}$ atau $\mathrm{kW}$. Untuk mengetahui SFC dapat digunakan persamaan berikut [6]:

$$
\mathrm{SFC}=\frac{G_{f}}{N_{e}}
$$

Keterangan:

SFC $=$ Konsumsi bahan bakar spesifik

$$
(\mathrm{kg} / \text { watt.jam })
$$

Biogas merupakan salah satu jenis energi yang dapat diperbaharui (renewable energy). Selain itu biogas juga merupakan sumber energi yang ramah lingkungan dan murah. Bahan baku pembuatan biogas merupakan bahan yang mudah didapatkan dan umumnya limbah organik, seperti kotoran ternak, sampah, limbah industri makanan, dan lain-lain. Biogas dibentuk dari hasil fermentasi anaerobik yang merupakan proses perombakan suatu bahan menjadi bahan lain yang lebih sederhana dengan bantuan mikroorganisme tertentu dalam keadaan tidak berhubungan langsung dengan udara bebas. Penggunaan biogas sebagai bahan bakar pada mesin generator set menurunkan emisi gas buang dibandingan dengan emisi gas buang $\mathrm{CO}_{2}$ yang dihasilkan oleh mesin generator set berbahan bakar bensin. Besarnya konsumsi bahan bakar ketika menggunakan bahan bakar bensin berkisar antara 103.110 $208.330 \mathrm{mg} / \mathrm{dt}$. Dan besarnya konsumsi bahan bakar ketika menggunakan bahan bakar biogas lebih rendah berkisar antara 83.333-159.997 mg/dt [7].

Sistem pengapian pada mesin pembakaran dalam khususnya motor bakar bensin berfungsi untuk mengatur tgerjadinya proses pembakaran antara campuran bahan bakar seperti bensin dan udara di dalam ruang bakar (silinder) sesuai waktu yang sudah ditentukan yaitu pada akhir langkah kompresi. Dengan demikian waktu penyalaan yang tepat akan mempengaruhi proses pembakaran yang sempurna. Pada motor bakar bensin, sistem pengapian terdiri dari beberapa komponen, yang bekerja bersama-sama dalam waktu yang sangat cepat dan singkat. Waktu penyalaan pada motor bensin dapat diatur pada posisi tertentu, dimana proses pengaturan waktu penyalaan disesuaikan dengan bahan bakar yang digunakan. Apabila waktu penyalaan atau pengapian dimajukan terlalu jauh maka tekanan pembakaran maksimum akan tercapai sebelum $10^{\circ}$ sesudah TMA. Karena tekanan di dalam silinder akan menjadi lebih tinggi dari pada pembakaran dengan waktu yang tepat, pembakaran campuran udara bahan bakar yang spontan akan terjadi dan akhirnya akan terjadi knocking atau detonasi. Knocking atau detonasi merupakan kondisi terjadinya ledakan yang menghasilkan gelombang kejutan berupa suara ketukan karena naiknya tekanan yang besar dan kuat yang terjadi pada akhir pembakaran. Saat pengapian yang terlalu maju juga bisa menyebabkan suhu mesin menjadi terlalu tinggi. Sedangkan bila saat pengapian dimundurkan terlalu jauh maka tekanan pembakaran maksimum akan terjadi setelah $10^{\circ}$ setelah TMA (saat dimana torak telah turun cukup jauh). Bila dibandingkan dengan pengapian yang waktunya tepat, maka tekanan di dalam silinder agak rendah sehingga output mesin menurun, dan masalah pemborosan bahan bakar dan lainnya akan terjadi. Saat pengapian yang tepat dapat menghasilkan tekanan pembakaran yang optimal [8].

\section{Metode Penelitian}

Lokasi penelitian dilakukan di Laboratorium Teknik Mesin Universitas Muhammadiyah Metro. Penelitian ini dilakukan dengan metode eksperimen nyata (true experimental research) dengan melakukan perancangan dan pembuatan serta pengujian sistem dual fuel (pertamax dan biogas) pada mesin sepeda motor. Variabel bebas pada penelitian ini yaitu temperatur biogas $\left(30^{\circ}, 40^{\circ}\right.$, dan $\left.50^{\circ} \mathrm{C}\right)$ dan waktu penyalaan $11^{\circ}, 13^{\circ}$, dan $15^{\circ}$ sebelum TMA. Proses pengujian kinerja motor menggunakan sistem bahan bakar dual fuel dilakukan dengan menghidupkan mesin 
motor menggunakan bahan bakar pertamax dan biogas yang kemudian dilakukan pengujian kinerja motor meliputi torsi, daya dan konsumsi bahan bakar. Pengujian kinerja motor menggunakan dynamometer tipe cakram.

Skema penelitian yang dilakukan dijelaskan pada gambar berikut.

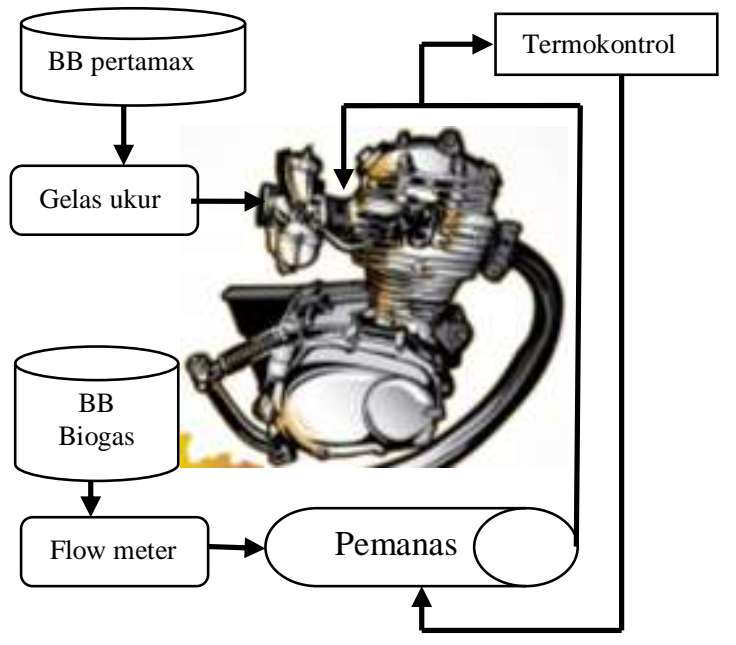

Gambar 1. Skema penelitian

\section{Hasil dan Pembahasan}

Pengujian kinerja motor menggunakan dynamometer tipe cakram. Prinsip kerja dari dymanometer ini yaitu dengan memberikan gaya pengereman pada poros yang terhubung dengan mesin motor bensin. Dengan pengereman ini maka akan diketahui besarnya gaya yang dihasilkan oleh mesin motor. Besarnya gaya tersebut digunakan untuk mengetahui torsi yang dihasilkan oleh mesin motor yang kemudian juga digunakan untuk menghitung daya motor. Untuk mengetahui besarnya daya motor maka perlu diketahui putaran poros motor yang dilakukan pengereman, sehingga besarnya daya motor dipengaruhi oleh putaran dan gaya pengereman. Pengujian juga dilakukan untuk mengetahui konsumsi bahan bakar pada motor. Pada Sistem dual fuel (pertamax-biogas) laju bahan bakar gas yang digunakan yaitu $2 \mathrm{~L} /$ menit. Pencampuran bahan bakar pertamax dan udara terjadi pada karburator, sedangkan penambahan bahan bakar biogas dilakukan pada intake manifold (sebelum masuk ruang bakar). Pengujian kinerja motor dilakukan pada putaran mesin maksimal $5000 \mathrm{rpm}$ sehingga daya yang dihasilkan belum pada daya maksimal yang mampu dihasilkan motor. Pengujian lebih difokuskan untuk mengetahui pengaruh temperatur biogas dan waktu penyalaan terhadap kinerja motor.

Berdasarkan analisa data hasil pengujian dan perhitungan kinerja motor maka diperoleh torsi yang dihasilkan motor dengan variasi termperatur biogas $\left(30^{\circ} \mathrm{C}\right.$, $40{ }^{\circ} \mathrm{C}$ dan $50{ }^{\circ} \mathrm{C}$ ) dan variasi waktu penyalaan $\left(11^{\circ}, 13^{\circ}\right.$, dan $15^{\circ}$ sebelum TMA) seperti pada gambar grafik berikut.

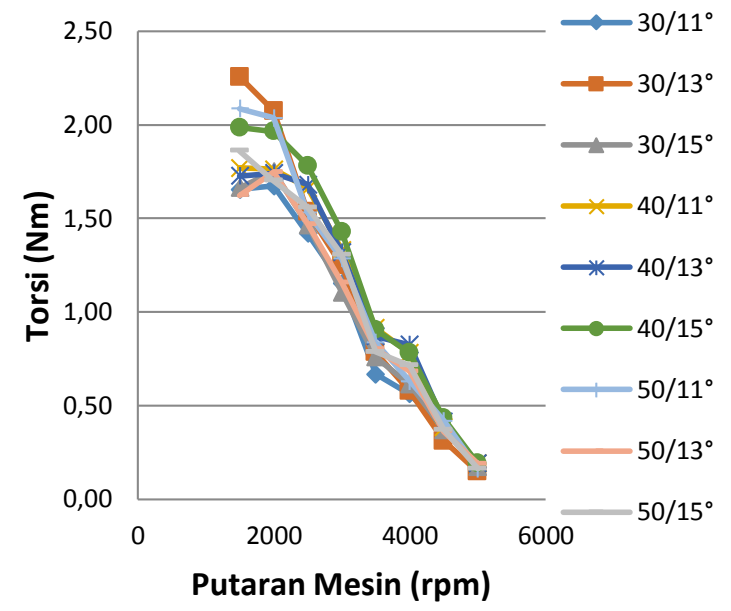

Gambar 2. Torsi mesin

Dari Gambar 2, torsi mesin dapat diketahui bahwa torsi yang dihasilkan semakin meningkat dengan penurunan putaran mesin. Hal ini terjadi karena metode pengujian yang dilakukan menggunakan sistem pengereman dengan dynamometer tipe cakram, sehingga semakin besar gaya pengereman akan semakin besar torsi yang dihasilkan, namun putaran mesin akan semakin menurun dengan semakin meningkatnya gaya pengereman. Grafik torsi yang dihasilkan selaras dengan hasil penelitian yang dilakukan oleh Bambang Yunianto 2009 yaitu torsi yang dihasilkan semakin meningkat dengan penurunan putaran mesin. Torsi tertinggi diperoleh pada variasi temperatur biogas $30^{\circ} \mathrm{C}$ dan waktu penyalaan $13^{\circ}$ sebelum TMA [8]. 
Berdasarkan hasil perhitungan dan analisa data diperoleh grafik daya yang dihasilkan motor seperti pada gambar grafik berikut.

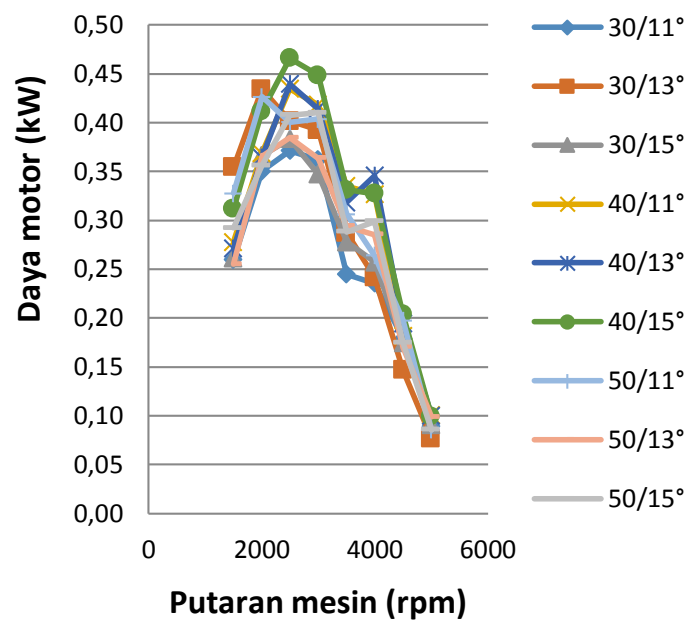

Gambar 3. Daya motor

Dari Gambar 3, daya motor diketahui bahwa temperatur biogas dan waktu penyalaan berpengaruh terhadap daya yang dihasilkan motor. Pola grafik daya yang dihasilkan pada penelitian ini selaras dengan hasil penelitian yang dilakukan oleh Atok Setiyawan 2007 [3] dan Bambang Yunianto 2009 [8]. Daya yang dihasilkan motor tertinggi pada putaran tertentu, sedangkan pada putaran lebih tinggi dan atau putaran rendah daya yang dihasilkan lebih rendah.

Berdasarkan hasil penelitian yang telah dilakukan diketahui bahwa daya motor tertinggi diperoleh dengan variasi temperatur biogas $40{ }^{\circ} \mathrm{C}$ dan waktu penyalaan $15^{\circ}$ sebelum TMA yaitu 466,12 Watt pada putaran mesin $2500 \mathrm{rpm}$. Hasil penelitian menunjukan bahwa temperatur biogas dan waktu penyalaan berpengaruh terhadap daya yang dihasilkan motor. Daya tertinggi diperoleh pada waktu penyalaan $15^{\circ}$ sebelum TMA, sedangkan pada $11^{\circ}$ dan $13^{\circ}$ sebelum TMA daya yang dihasilkan lebih rendah. Pada penelitian yang dilakukan oleh Bambang Yunianto 2009 daya tertinggi diperoleh pada derajat pengapian $11^{\circ}$ sebelum TMA dengan variasi derajat pengapian $11^{\circ}, 14^{\circ}$ dan $17^{\circ}$ [8]. Dalam hal ini terjadi perbedaan daya maksimal yang dihasilkan motor pada waktu penyalaannya (waktu pengapian/Ignition Timing). Pada penelitian yang telah dilakukan daya maksimal terjadi pada waktu penyalaan data derajat pengapian $15^{\circ}$ sebelum TMA sedangkan pada penelitan yang dilakukan oleh Bambang Yunianto pada $11^{\circ}$ sebelum TMA. Hal tersebut terjadi karena bahan bakar yang digunakan pada penelitian Bambang Yunianto yaitu Liquified Petroleum Gas (LPG)[8]. Menurut KSME International Journal, VoL $16 \mathrm{No}$. 7, pp. 935 941, 2002 Analysis of Combus-tion and Flame Propagation Characteristics of LPG and Gasoline Fuels by Laser Deflection Method disebutkan bahwa LPG terbakar lebih cepat dari bensin pada kondisi $\lambda>1$ [9]. Sehingga pada derajat pengapian $11^{\circ}$ dengan bahan bakar LPG daya yang dihasilkan lebih tinggi dibandingkan dengan $14^{\circ}$ dan $17^{\circ}$.

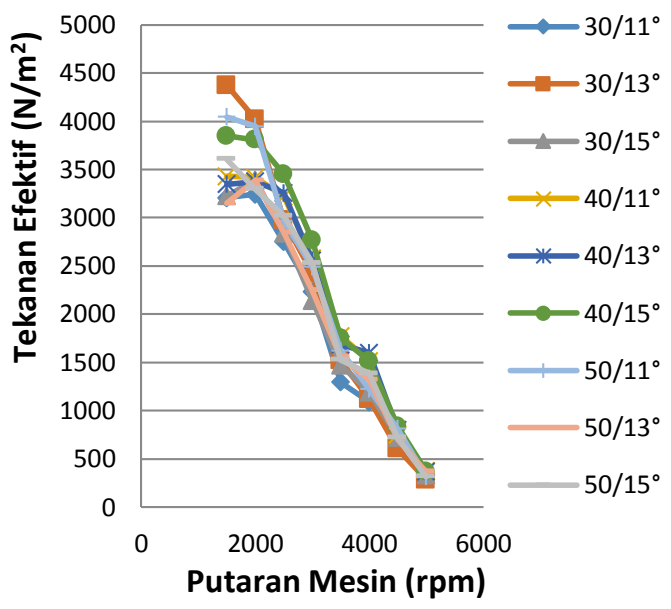

Gambar 4. Tekanan efektif ruang bakar

Berdasarkan Gambar 4, tekanan efektif ruang bakar diketahui bahwa temperatur bahan bakar dan waktu penyalaan berpengaruh terhadap tekanan yang terjadi pada ruang bakar. Tekanan tertinggi diperoleh dengan variasi $30{ }^{\circ} \mathrm{C}$ dan waktu penyalaan $13^{\circ}$ sebelum TMA. Tekanan efektif merupakan tekanan yang terjadi pada ruang bakar yang disebabkan oleh pembakaran bahan bakar dan juga dipengaruhi oleh putaran mesin. Pada variasi temperatur biogas $30{ }^{\circ} \mathrm{C}$ dan waktu 
penyalaan $13^{\circ}$ sebelum TMA daya tertinggi diperoleh pada putaran $2000 \mathrm{rpm}$ sehingga mampu menghasilkan tekanan yang lebih tinggi dibandingkan variasi yang lain. Tekanan pada ruang bakar dipengaruhi oleh tekanan yang disebabkan oleh hasil pembakaran. Pada kondisi penyalaan yang tepat akan menghasilkan tekanan yang tinggi pada ruang bakar. Namun pada variasi $30{ }^{\circ} \mathrm{C}$ dan waktu penyalaan $13^{\circ}$ sebelum TMA putaran mesin cenderung lebih rendah sehingga daya yang dihasilkan juga rendah.

Berdasarkan hasil perhitungan diperoleh grafik konsumsi bahan bakar spesifik motor pada masing-masing variasi pengujian yaitu:

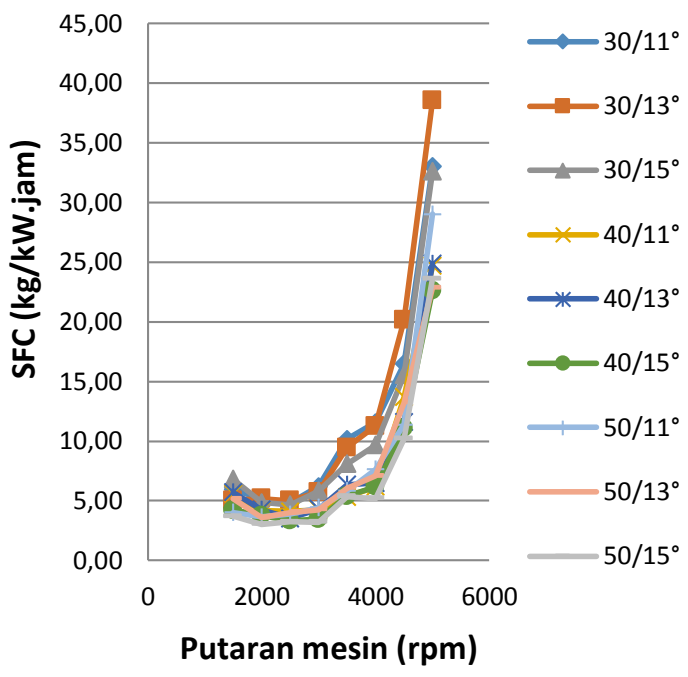

Gambar 5. Konsumsi bahan bakar spesifik

Dari Gambar 5, konsumsi bahan bakar spesifik diketahui bahwa variasi temperatur bahan bakar dan waktu penyalaan berpengaruh terhadap konsumsi bahan bakar spesifik motor. Konsumsi bahan bakar spesifik merupakan nilai perbandingan antara jumlah bahan bakar dalam waktu tertentu dengan daya yang mampu dihasilkan. Pada penelitian yang telah dilakukan diketahui bahwa konsumsi bahan bakar spesifik terbaik diperoleh pada variasi temperatur $50^{\circ} \mathrm{C}$ dan waktu penyalaan $15^{\circ}$ sebelum TMA yaitu 3,0 $\mathrm{kg} / \mathrm{kW}$ jam. Hasil penelitian yang telah dilakukan selaras dengan penelitian sebelumnya yang dilakukan oleh
Mafruddin dkk. 2019 [4]. Pada penelitian tersebut konsumsi bahan bakar spesifik terbaik diperoleh pada temperatur vaporasi bahan bakar $50{ }^{\circ} \mathrm{C}$ menggunakan sistem vaporasi bahan bakar. Dimana variasi penelitiannya yaitu temperatur $40^{\circ} \mathrm{C}, 50^{\circ} \mathrm{C}$ dan $60^{\circ} \mathrm{C}$. Hasil penelitian juga sesuai dengan teori termodinamika yang menyatakan bahwa tinggi temperatur suatu fluida molekul fluida akan bergerak cepat, sehingga pada volume tetap secara makro akan meningkatkan tekanan [10]. Pada penelitian yang telah dilakukan pencampuran bahan bakar pertamax (pertamax-udara) dan biogas terjadi pada sisi intake manifold (sebelum masuk ruang bakar) sehingga jika bahan bakar biogas dipanaskan maka secara otomatis bahan bakar pertamax akan ikut naik karena terjadi perpindahan panas antara bahan bakar biogas dan pertamax. Dengan meningkatnya temperatur kedua bahan bakar tersebut maka viskositas bahan bakar biogas dan pertamax lebih rendah. Dengan menurunnya viskositas bahan bakar maka bahan bakar tersebut akan teratomisasi dengan lebih baik dan menghasilkan butiran bahan bakar yang lebih kecil sehingga proses pencampuran bahan bakar dengan udara akan lebih homogen yang berdampak pada proses pembakaran yaitu bahan bakar yang terbakar lebih banyak [5]. Pada kondisi bahan bakar yang terbakar lebih banyak dengan pembakaran yang sempurna maka energi yang dilepaskan pada proses pembakaran tersebut akan meningkat sehingga tekanan pada akhir proses pembakaran juga akan meningkat. Hal ini yang menyebabkan konsumsi bahan bakar spesifik pada temperatur $50^{\circ} \mathrm{C}$ lebih baik dibandingkan dengan variasi temperatur lainnya meskipun jumlah bahan bakar biogas yang digunakan sama pada masing-masing variasi. Namun konsumsi bahan spesifik yang dihasilkan masih cukup tinggi, hal tersebut terjadi karena pada proses pengujian dilakukan pada putaran yang rendah (maksimal $5000 \mathrm{rpm}$ ), sehingga 
kinerja motor belum sampai pada titik maksimalnya.

\section{Kesimpulan}

Dari hasil penelitian dapat disimpulkan bahwa temperatur biogas dan waktu penyalaan berpengaruh terhadap kinerja motor. Daya tertingi diperoleh dengan variasi temperatur biogas $40^{\circ} \mathrm{C}$ dan waktu penyalaan $15^{\circ}$ sebelum TMA. Sedangkan konsumsi bahan bakar spesifik terbaik diperoleh pada variasi temperatur biogas $50^{\circ} \mathrm{C}$ dan waktu penyalaan $15^{\circ}$ sebelum TMA.

\section{Referensi}

[1] Sunaryo, S. (2014). Uji Eksperimen Pemurnian Biogas Sebagai Pengganti Bahan Bakar Motor Bensin. Jurnal Penelitian dan Pengabdian Kepada Masyarakat UNSIQ, 1(2), 123-130.

[2] Kristanto, P., Anggono, W., \& Wahyudi, D. (2004). Pengaruh perubahan pemajuan waktu penyalaan terhadap motor dual fuel (bensin-BBG). Jurnal Teknik Mesin, 3(1), pp-1.

[3] Setiyawan, A. (2007). Pengaruh Ignition Timing dan Compression Ratio Terhadap unjuk Kerja dan Emisi Gas Buang Motor Bensin Berbahan Bakar Campuran Etanol $85 \%$ dan Premium 15\%(E-85). In Seminar Nasional Teknologi (pp. 3-8).

[4] Mafruddin, M., Segara, C. G., \& Dharma, U. S. (2019). Kinerja Mesin Sepeda Motor dengan Sistem Vaporasi Bahan Bakar. Turbo: Jurnal Program Studi Teknik Mesin, 8(1).

[5] Sanata, A., (2012). Optimalisasi Prestasi Mesin Bensin Dengan Variasi Temperatur Campuran Bahan Bakar Premium Dan Etanol. Jurnal ROTOR, Volume 5 Nomor 2, Juli 2012.

[6] Arismunandar, Wiranto. 1983. Penggerak mula motor bakar torak. Teknik Mesin. ITB. Bandung.
[7] Prastya, R., Susilo, B., \& Lutfi, M. (2013). Pengaruh Penggunaan Bahan Bakar Biogas terhadap Emisi Gas Buang Mesin Generator Set. Jurnal Keteknikan Pertanian Tropis dan Biosistem, 1(2).

[8] Yunianto, B. (2009). pengaruh perubahan saat penyalaan (ignition timing) terhadap prestasi mesin pada sepeda motor 4 langkah dengan bahan bakar lpg. Rotasi, 11(3), 1-4.

[9] Lee, K.H., Lee, C.S., Ryu, J.D. et al. Analysis of combustion and flame propagation characteristics of LPG and Gasoline fuels by laser deflection method. KSME

International Journal 16, 935-941 (2002). https://doi.org/10.1007/BF02949722.

[10] Hamid, A. A. (2007). Kalor dan termodinamika. Universitas Negeri Yogyakarta. 